\title{
Changes in quality characteristics of 'Makgeolli' prepared by independent two-step fermentation during storage
}

\author{
Hyun-Soo Kim ${ }^{1,2 \ddagger}$, Jeong Sil Choi ${ }^{2 \ddagger}$, Seok Hun $\mathrm{Yu}^{3}$, Myung Kon Kim ${ }^{1}$, \\ Bora Lim $^{2}$, Seok Tae Jeong ${ }^{2 *}$ \\ ${ }^{1}$ Department of Food Technology, Chonbuk National University, Jeonju 57997, Korea \\ ${ }^{2}$ Fermented Food Science Division, National Institute of Agricultural Science, Wanju 55365, Korea \\ ${ }^{3}$ Sintanjinjujo, Daejeon 34336, Korea
}

\section{단행복발효 막걸리의 저장 중 품질 특성 변화 \\ 김현수 ${ }^{1,2 \ddagger}$. 최정실 ${ }^{2 \ddagger} \cdot$ 유석헌 $^{3} \cdot$ 김명곤 $^{1}$ - 임보라 ${ }^{2}$. 정석태 ${ }^{2 *}$ \\ 1전북대학교 식품공학과, ${ }^{2}$ 국립농업과학원 발효가공식품과, ${ }^{3}$ 농업회사법인신탄진주조(주)}

\begin{abstract}
This study investigated changes in the quality of the Korean sparkling rice wine, 'Makgeolli' prepared by independent two-step fermentation and stored at 10,15 , and $25^{\circ} \mathrm{C}$ for 91 days. The contents of total acid, volatile acid, and amino acidity increased as the storage period and temperature increased. The total acid content was $0.14 \%$ on day 0 , and $0.33 \%, 0.35 \%$ and $0.40 \%$ at 91 days of storage at $10^{\circ} \mathrm{C}, 15^{\circ} \mathrm{C}$, and $25^{\circ} \mathrm{C}$, respectively. The pH was 3.86 on day 0 of storage and tended to decrease at all temperatures over the storage period, but the soluble solid and alcohol content did not significantly differ. Color significantly differed when stored at $15^{\circ} \mathrm{C}$ and $25^{\circ} \mathrm{C}(p<0.05)$, but not at $10^{\circ} \mathrm{C}$. Consequently, the quality of 'Makgeolli' was altered during storage for 91 days, and the change was more rapid at higher storage temperatures.
\end{abstract}

Key words : Makgeolli, independent two-step fermentation, storage, quality changes

서 론

막걸리는 주로 찹쌀이나 멥쌀을 원료로 하고 발효제로 누 룩을 사용하여 만들어지는 발효주로 전분질은 누룩에 함유되 어 있는 당화효소에 의해 분해되어 당분이 생성되고, 이 당분 은 효모에 의해 혐기적 상태에서 알코올로 전환시키는 과정 이 동시에 일어나는 병행복발효주이다(Son 등, 2011).

한편, 술의 발효법 중 단행복발효는 당화와 알코올 발효를 따로 분리해서 발효시키는 방식으로 쌀을 삭혀 단맛이 있는 식혜와 같은 음료로 만든 뒤 효모를 접종하는 방식이다. 강원 도의 옥수수술이 이런 방식으로 만드는 대표적인 술로 최근
막걸리 제조장에서도 단행복발효를 이용한 막걸리가 제조되 고 있다고 한다(Ryu, 2014). 단행복발효 방식의 대표적인 주 류는 맥주로, 맥주는 제조 공정 중 맥즙을 살균하는 자비 공 정을 통해 세균과 곰팡이 등 미생물을 사멸시켜 자비 공정 이후 미생물 오염이 없도록 한다(Jeong 등, 2015). 따라서 당 화액을 열처리한 후 효모를 접종하므로 맛 성분과 향기 성분 을 비롯하여 품질 특성 변화 또한 적을 것으로 예상된다.

병행복발효 방식으로 만들어지는 기존의 막걸리에는 Aspergillus, Rhizopus, Mucor 속 등의 곰팡이와 Saccharomyces, Pichia, Candida, Torulopsis, Hansenular 속 등의 효모와 Bacillus, Micrococcus, Aerobacter, Pseudomonas 속 등의 세

*Corresponding author. E-mail : jst@korea.kr, Phone : +82-63-238-3615, Fax : +82-63-238-3843

Received 07 July 2020; Revised 16 September 2020; Accepted 18 September 2020.

Copyright (c) The Korean Society of Food Preservation.

This is an Open Access article distributed under the terms of the Creative Commons Attribution Non-Commercial License (http://creativecommons.org/licenses/by-nc/4.0) which permits unrestricted non-commercial use, distribution, and reproduction in any medium, provided the original work is properly cited. 
균이 검출될 수 있다. 따라서 막걸리는 유통과정 중에도 이들 미생물에 의하여 막걸리에 함유되어 있는 잔류 영양 성분으 로 발효가 진행되고, 잡균이나 초산균에 의해 부패나 산패되 어 산도가 증가하는 문제점이 있다(Lee와 Rhee, 1970; Lee 등, 1991). 이와 같은 문제점은 유통과정 중에 잔존하는 당류 의 지속적인 발효로 단맛이 낮아짐에 따라 신맛과 쓴맛이 상 대적으로 증가하게 되는 등 품질의 불균일화를 야기시킨다 (Bae 등, 1990; Lee 등, 1989).

막걸리의 품질 변화 원인을 확인하기 위해 막걸리 저장 및 유통 중 품질변화에 대한 연구가 진행되었으며(Choi 등, 2012; Lee 등, 2009), 품질 변화 방지 및 저장성 개선을 위해 저온 살균(Lee 등, 1991), UV살균(Lee 등, 2009), 초고압처리(Jwa 등, 2001)에 대한 연구가 진행된 바 있다. 또한, 저장성 개선 을 위한 효모 탐색(Baek 등, 2011)과 천연첨가물 첨가(Jeong 등, 2006)에 대한 연구도 진행되었다. 그렇지만 단행복발효 방식으로 제조된 막걸리의 저장 중 품질 변화에 관한 연구는 진행된 바가 없는 것으로 사료된다.

앞에서도 언급했듯이, 맥주의 경우 당화와 발효가 따로 진 행되는 단행복발효 방법으로 제조되고, 당화 과정 후 자비과 정에서 맥즙을 $90^{\circ} \mathrm{C}$ 이상으로 살균하여 미생물로 인한 맥주 의 오염 방지와 효소 불활성으로 인한 맥즙의 조성 변화를 막아 품질 변화를 방지하고 있다(Jeong 등, 2015). 반면, 막걸 리는 병행복발효 방법으로 당화와 발효가 동시에 진행되고, 맥주의 자비와 같은 과정이 없어 제성 후에도 막걸리 속에 들어있는 위해 미생물에 의해 막걸리 품질 변화를 야기시킨 다(Lee 등, 1996; Song 등, 1997). 이에 본 연구에서는 원료 및 누룩에서 유래될 수 있는 위해 미생물 및 효소를 제어함으 로써 저장성을 증진시킨 막걸리 개발에 관한 연구의 일환으 로 단행복발효 방법을 막걸리에 접목하여 당화, 살균, 발효 과정 순으로 막걸리를 제조하고, 저장 온도에 따른 막걸리의 품질 변화에 대해 알아보고자 하였다.

\section{재료 및 방법}

\section{실험재료}

막걸리 제조용 원료는 2016년산 오대미(Dongsong Nonghyup, Cheolwon, Korea)를, 밀가루는 시중에서 판매하는 중력분 밀가루(CJ Cheiljedang Co., Ltd., Yangsan, Korea)를 사용하 였다. 발효제는 역가 $300 \mathrm{SP}$ 의 송학곡자(Songhakgokja Co., Gwangju, Korea)와 $15,000 \mathrm{sp}$ 의 충무정제효소(Chungmubalhyo Co., Ulsan, Korea)를 사용하였다. 효모는 Saccharomyces bayanus EC-1118(Lallemand Inc, Montreal, Canada)을 사용 하였다. 첨가제는 젖산(Musashino Chemical Laboratory Ltd., Tokyo, Japan)과 함수결정포도당(Daesang Corp., Gunsan,
Korea), 자일리톨(Samin Chemical Co., Siheung, Korea)을 사용하였다. 용수는 대전광역시 대덕구 신탄진로 738 번길 128 신탄진주조의 수도를 이용하였다.

\section{막걸리 제조}

막걸리 제조는 신탄진주조에서 진행하였으며, 제조 방법은 다음과 같다. 즉, 쌀 $120 \mathrm{~kg}$ 을 세척하고 3시간 수침, 1 시간 탈수를 한 뒤 밀가루 $30 \mathrm{~kg}$ 과 혼합하여 $100^{\circ} \mathrm{C}$ 에서 1 시간 증 자하였다. 증자한 원료는 젖산 $1.125 \mathrm{~kg}$, 송학곡자 $7.5 \mathrm{~kg}$, 충 무정제효소 $2.85 \mathrm{~kg}$ 을 미리 풀어놓은 용수 $450 \mathrm{~L}$ 에 혼합하여 $55^{\circ} \mathrm{C}$ 에서 12 시간 당화시켜 당화액을 만들어 주었다. 당화가 완료되면 당화액을 여과하고 품온을 $100^{\circ} \mathrm{C}$ 까지 가열하여 2 분간 유지시켜 주었다. 그 후 당화액을 $25^{\circ} \mathrm{C}$ 까지 냉각시켜 주 고, 효모 $50 \mathrm{~g}(0.01 \%)$ 을 접종하여 7일간 1차 발효를 진행하 였다. 1 차 발효 완료 후 용수 $450 \mathrm{~L}$ 를 첨가하여 알코올 함량 을 $5.5 \%$ 로 맞추고 자일리톨과 함수결정포도당을 각각 $9 \mathrm{~kg}$ 씩 첨가하였다. 그 후 $600 \mathrm{~mL}$ 내압용 P · P 용기에 병입하여 $15^{\circ} \mathrm{C}$ 에서 7일간 2차 발효를 진행하였고, 발효 완료 후 각각 의 저장 온도에서 저장하였다.

\section{저장 조건 및 시료 채취}

단행복발효 막걸리의 저장은 냉장룸(UC-33001L, Kukje Co., Cheonan, Korea)에 막걸리의 유통온도인 $10^{\circ} \mathrm{C}$ 를 포함하 여 $15^{\circ} \mathrm{C}$ 와 $25^{\circ} \mathrm{C}$ 에서 저장하였고, 7 일 간격으로 각각의 온도 에 저장된 막걸리 중 3 병을 무작위로 선택하여 분석하였다.

\section{이화학 성분 분석}

단행복발효 막걸리의 이화학 성분 분석은 국세청 주류분석 규정을 따랐다(National Tax Service Liquors License Support Center, 2014). 즉, $\mathrm{pH}$ 는 $\mathrm{pH}$ meter(Orion 3 Star Benchtop pH meter, Thermo Fisher Scientific Inc., Waltham, MA, USA)로 측정하였다. 총산은 시료 $10 \mathrm{~mL}$ 를 취하여 $100 \mathrm{~mL}$ 용 삼각플라스크에 넣고 $0.1 \mathrm{~N} \mathrm{NaOH}$ (Yakuri Pure Chemical Co., Ltd., Kyoto, Japan) 용액으로 $\mathrm{pH}$ 8.2가 될 때까지 적정 하여 그 값을 초산 $\%(\mathrm{w} / \mathrm{v})$ 으로 환산하여 나타내었다. 아미노 산도는 시료 $10 \mathrm{~mL}$ 를 $100 \mathrm{~mL}$ 삼각플라스크에 취한 다음, 페놀프탈레인 지시약 2-3방울을 가하여 $0.1 \mathrm{~N} \mathrm{NaOH}$ 용액으 로 엷은 분홍색이 나올 때까지 적정하였다. 여기에 중성포르 말린 용액(Yakuri Pure Chemical Co., Ltd.) $5 \mathrm{~mL}$ 를 넣어 원 래의 색이 나오게 한 후 다시 $0.1 \mathrm{~N} \mathrm{NaOH}$ 용액으로 엷은 분홍색이 나올 때까지 적정하여 소비된 용액의 양 $(\mathrm{mL})$ 으로 표시하였다. 가용성 고형분( $\left.{ }^{\circ} \mathrm{Brix}\right)$ 함량은 디지털 굴절계 (PR-201, Atago Co., Tokyo, Japan)를 사용하여 측정하였다. 알코올 함량은 시료 $100 \mathrm{~mL}$ 를 증류 및 냉각 장치에 연결한 
후 가열하여 증류액을 약 $80 \mathrm{~mL}$ 이상 받고 $100 \mathrm{~mL}$ 까지 증 류수로 정용하였다. 증류액을 잘 혼합한 다음 주정계 (Dongmyeong, Seoul, Korea)를 사용하여 눈금을 읽고 주정 분 온도 환산표로서 $15^{\circ} \mathrm{C}$ 로 보정하여 알코올 농도 $(\%, \mathrm{v} / \mathrm{v})$ 함 량으로 나타내었다. 또는 증류액을 $15^{\circ} \mathrm{C}$ 로 조정하여 알코올 분석기(AL-3, Riken Keiki, Tokyo, Japan)를 이용하여 측정하 였다. 휘발산 함량은 알코올 분석용 증류액 $30 \mathrm{~mL}$ 를 취하여 삼각플라스크에 넣고 $0.01 \mathrm{~N} \mathrm{NaOH}$ 로 $\mathrm{pH}$ 8.2가 될 때까지 적정하여 소비된 $0.01 \mathrm{~N} \mathrm{NaOH}$ 를 초산으로 환산하여 표시하 였다. 색도는 색차계(Hunterlab Ultra Scan Pro, Reston, VA, USA)를 이용하여 명도(lightness, L), 적색도(redness, a), 황색 도(yellowness, b) 및 색차 $(\Delta \mathrm{E})$ 값을 측정하여 나타내었다.

\section{통계분석}

모든 데이터는 3 회 반복 측정하였으며, 평균 \pm 표준편차로 표시하였다. 통계분석은 SPSS 프로그램 18.0 버전을 이용하 여 품질특성에 대하여 처리구간의 유의적인 차이를 알아보기 위해 일원분산분석(One-way ANOVA)을 실시하였다. 시료 간 유의적인 차이가 있을 경우, $\alpha=0.05$ 수준에서 Duncan의 다중범위 검정을 실시하였다.

\section{결과 및 고찰}

\section{막걸리의 저장 기간 중 $\mathrm{pH}$ 변화}

막걸리의 $\mathrm{pH}$ 는 성분변화를 쉽게 알 수 있는 요인으로 유 기산, 탄산가스, 산성 아미노산, 기타 산 물질 등과 관련이 있 다(Song 등, 1997). 저장기간에 따른 저장 온도별 막걸리의 $\mathrm{pH}$ 변화는 Fig. 1 과 같다. 저장초기 0 일 차의 $\mathrm{pH}$ 는 3.86 으로 Park 등이 연구한 시판 막걸리의 $\mathrm{pH}$ 범위에 포함된 수치였다 (Park 등, 2011). $10^{\circ} \mathrm{C}$ 저장 시 91일 차까지 3.44로 완만하게 감소하였다. $15^{\circ} \mathrm{C}$ 저장 시 49 일 차까지 3.44 로 감소하였으나 91 일 차에 3.51 로 증가하였고, $10^{\circ} \mathrm{C}$ 에 비해 감소 속도가 더 빨랐다. $25^{\circ} \mathrm{C}$ 저장 시 7 일 차에 3.56 으로 급격히 감소한 뒤 91일 차까지 그 수준을 유지하였다. 저장 기간이 경과함에 따 라 모든 저장 온도에 $\mathrm{pH}$ 는 감소하는 경향을 나타내었다. 이 는 Jang 등의 연구에서 저장 기간이 경과함에 따라 $\mathrm{pH}$ 가 감 소한다는 결과와 같은 경향을 나타내었다(Jang 등, 2015). 반 면, 병행복발효 막걸리인 시판 살균 및 비살균 막걸리를 수거 하여 실온 $\left(25^{\circ} \mathrm{C}\right)$ 과 냉장 $\left(4^{\circ} \mathrm{C}\right)$ 에서 저장하면서 품질변화를 살 펴본 연구에서는 비살균 막걸리의 $\mathrm{pH}$ 가 저장기간에 따라 증 가하였지만, 실온 $\left(25^{\circ} \mathrm{C}\right)$ 에서의 저장 막걸리보다는 냉장 $\left(4^{\circ} \mathrm{C}\right)$ 에서 저장한 막걸리의 경우, 약간 증가함을 알 수 있었다. 이 것으로 저장 온도가 변화를 작게 한다는 것을 알 수 있다 (Choi 등, 2012). 본 연구에서도 온도가 낮은 $10^{\circ} \mathrm{C}$ 에서의 저

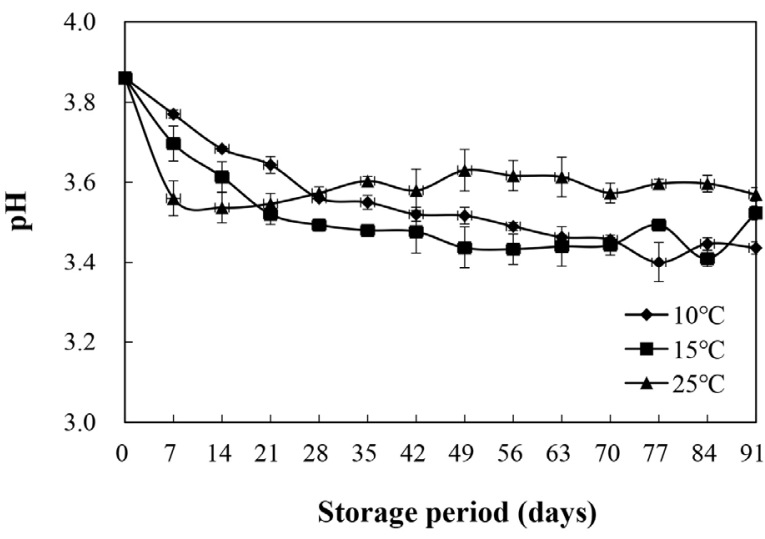

Fig. 1. Changes in pH of 'Makgeolli' during storage at different temperatures.

장에서 작은 변화를 알 수 있었다.

\section{막걸리의 저장 기간 중 총산 함량 변화}

저장 기간에 따른 저장 온도별 막걸리의 총산 함량 변화는 Fig. 2 와 같다. 총산은 저장 초기 0 일 차에 $0.14 \%$ 이었던 것이 $10^{\circ} \mathrm{C}$ 저장 시 91 일 차에 $0.33 \%, 15^{\circ} \mathrm{C}$ 저장 시 91 일 차에 $0.35 \%, 25^{\circ} \mathrm{C}$ 저장 시 91 일 차에 $0.40 \%$ 로 저장 기간과 저장 온도가 증가할수록 총산이 증가하는 경향을 나타내었다. 저 장 기간과 저장 온도가 증가할수록 총 산은 증가하였고, $\mathrm{pH}$ 와는 반대의 결과였다. 이는 $\mathrm{pH}$ 의 감소와 함께 총산이 유의 적으로 증가하고 저온에서의 변화가 적었던 Kim과 $\mathrm{Han}$ 의 연구 결과와 동일하였다(Kim과 Han, 2012). 반면, 총산도가 젖산으로 $0.35 \%$ 인 시판 살균 막걸리와 시판 비살균 막걸리를 실온 $\left(25^{\circ} \mathrm{C}\right)$ 와 냉장 $\left(4^{\circ} \mathrm{C}\right)$ 에서 저장하면서 살펴본 결과, 살균 여부와 상관없이 10 일 경과 후 $0.40 \%$ 로 약간 증가하였고, 30 일 후에는 $0.30-0.39 \%$ 수준으로 큰 차이를 보이지 않는 것으

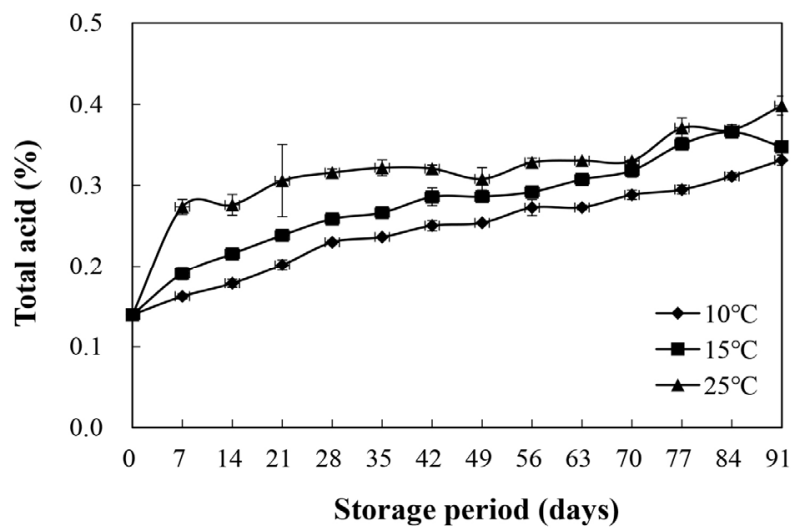

Fig. 2. Changes in total acid (\%) of 'Makgeolli' during storage at different temperatures. 
로 나타났다(Choi 등, 2012). 총산의 증가는 미생물 작용으로 생성된 각종 유기산에 의해 증가되는 것으로 추정되고(Song 등, 1997), 따라서 막걸리 저장 시 저장 기간 및 저장 온도가 막걸리 품질 변화에 주요 요인으로 사료된다.

\section{막걸리의 저장 기간 중 아미노산도 변화}

아미노산도는 술에 담백한 맛을 부여하는 성분으로 과다 할 경우 술덧이 노주화된 것 같은 느끼한 맛을 내 품질 저하 를 야기시킨다고 Kim은 보고하였다(Kim, 1963). 아미노산도 는 원료에 함유되어 있는 단백질이 누룩 중의 미생물이 생산 하는 단백질 분해 효소인 acid protease나 peptidase 등의 효 소 작용으로 생성된다(Lee 등, 1996). 저장 기간에 따른 저장 온도별 막걸리의 아미노산도 변화는 Fig. 3 과 같다. 저장 초 기 0 일 차의 아미노산도 0.17 로 Kang 등은 20 종의 시판 막걸 리 아미노산도 분석 결과와 비교하였을 때 현저히 낮은 수치 임을 확인할 수 있었다(Kang 등, 2014). 이는 막걸리 제조 시 당화액을 가열하는 과정으로 인해 단백질 분해 효소가 실활 되어 단백질을 분해하지 못한 것으로 사료된다. 저장 기간에 따른 저장 온도별 막걸리의 아미노산도 변화로는 $10^{\circ} \mathrm{C}$ 저장 시 91 일 차에 $0.37,15^{\circ} \mathrm{C}$ 저장 시 91 일 차에 $0.43,25^{\circ} \mathrm{C}$ 저장 시 91 일 차에 0.55 로 저장 기간과 저장 온도가 증가할수록 아미노산도가 증가하는 경향을 나타내었다. 이는 저장 온도 와 저장 기간이 증가할수록 아미노산도가 증가한다는 $\mathrm{Kim}$ 의 연구와 같은 결과였다(Kim, 2012). 본 연구에서는 막걸리 제 조 시 당화액을 가열하는 과정으로 인해 단백질 분해효소가 실활되었기 때문에 아미노산도의 증가는 제조 중 분해되지 않은 단백질이 발효미생물의 단백질 분해능과 효모의 자가소 화에 의한 것으로 추정되고, 저장 온도가 높을수록 아미노산 도가 높은 것은 저장 온도와 단백질 분해효소 활성이 비례적 인 관계이기 때문으로 사료된다(Cheong 등, 2015; Jung과

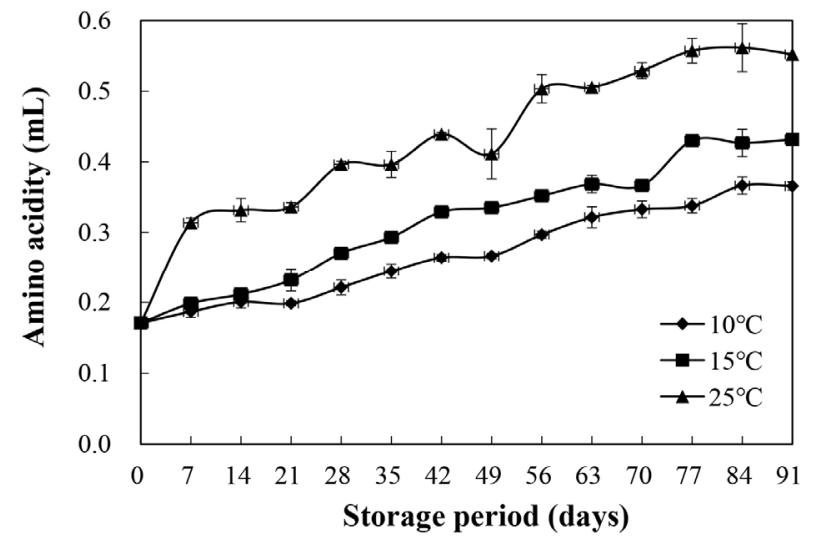

Fig. 3. Changes in amino acidity (mL) of 'Makgeolli' during storage at different temperatures.
Jung, 1985; Kim, 2012).

\section{막걸리의 저장 기간 중 가용성 고형분 함량 변화}

저장 기간에 따른 저장 온도별 막걸리의 가용성 고형분 함 량 변화는 Fig. 4 와 같다. 가용성 고형물 함량의 경우 모든 저장 온도에서 91일 차까지 경향성을 나타내는 변화는 없었 다. Son 등의 연구에 의하면 효모는 당분을 소모시키기 때문 에 발효 및 저장 중 가용성 고형분에 변화를 주는 것으로 보 고하였다(Son 등, 2011). 본 연구에서는 가용성 고형분의 경 향적인 변화가 없어 효모가 이용할 수 있는 당분이 미량일 것으로 추정된다. 그렇지만 효모에 의한 알코올 생성이 굴절 계에 영향을 주어 원래의 당분보다 높게 나왔을 것으로 사료 된다(Rogerson과 Symington, 2006).

\section{막걸리의 저장 기간 중 알코올 함량 변화}

알코올은 누룩의 amylase작용으로 전분질이 당분으로 분 해되면서 효모 발효에 의해 생성된다(Bae 등, 2002). 저장 기간에 따른 저장 온도별 막걸리의 알코올 함량 변화는 Fig. 5 와 같다. 본 실험에서 알코올 함량의의 경우, 모든 저장 온 도에서 91 일 차까지 큰 차이를 나타내지 않았다. Kim과 $\mathrm{Han}$ 의 연구에 의하면 발효 및 저장 단계에서도 많은 수의 효모가 살아있다고 보고하였고(Kim과 Han, 2012), Lee 등 은 저장 기간과 저장 온도가 증가할수록 알코올 함량이 증 가한다고 보고하였다(Lee 등, 2009). 그렇지만 본 연구의 경 우, 막걸리 제조 과정에서 완전 발효를 진행하여 효모의 영 양원인 당분이 고갈되어 효모가 알코올 발효를 못했을 것으 로 추정된다.

\section{막걸리의 저장 기간 중 휘발산 함량 변화}

휘발산은 주로 초산으로서 휘발산 함량이 많다는 것은 발

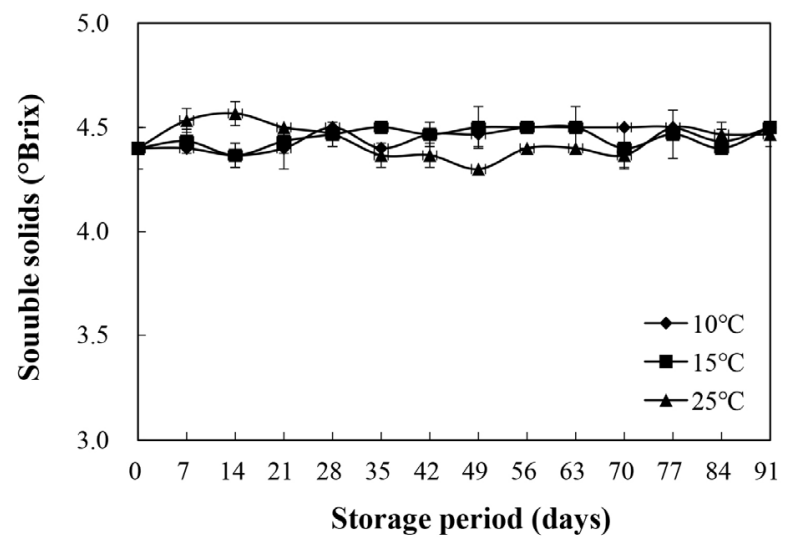

Fig. 4. Changes in soluble solid ( ${ }^{\circ}$ Brix) of 'Makgeolli' during storage at different temperatures. 


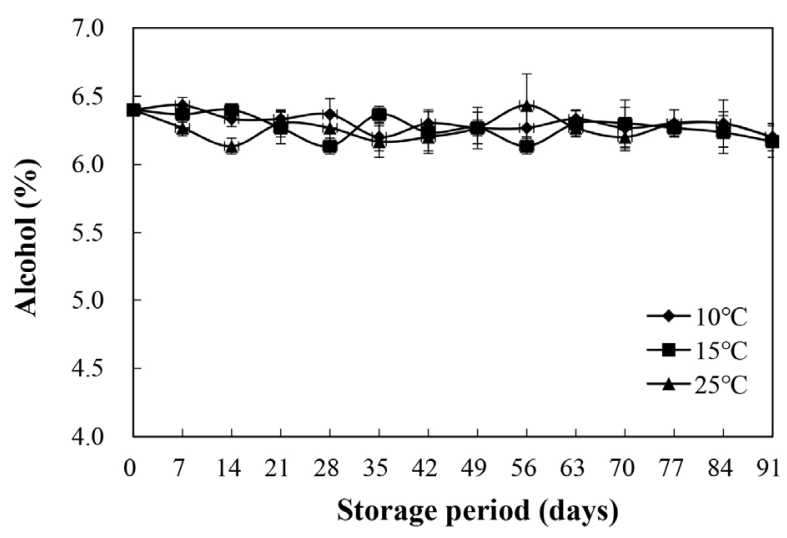

Fig. 5. Changes in alcohol (\%) of 'Makgeolli' during storage at different temperatures.

효나 저장 중 초산균에 의한 이상 발효가 진행되었다는 것을 간접적으로 나타낸다(Graham, 1993). Kang 등(2014)이 연구 한 20종의 시판 막걸리 휘발산 함량은 21.4-121.0 ppm으로 보고하였고, 본 연구에서 저장 초기 0 일 차의 막걸리의 휘발 산 함량은 $87.80 \mathrm{ppm}$ 이다. 따라서 본 연구에서 제조한 막걸 리의 휘발산 함량은 일반적인 막걸리에서 생성되는 수준으로 안전하게 발효되었음을 확인할 수 있었다. 저장 기간에 따른 저장 온도별 막걸리의 휘발산 함량 변화는 Fig. 6 과 같다. $10^{\circ} \mathrm{C}$ 저장 시 91일 차까지 $153.40 \mathrm{ppm}$ 으로 완만한 증가를 나타내 었다. $15^{\circ} \mathrm{C}$ 저장 시 56 일 차까지 완만하게 증가 후 91 일 차에 $321.67 \mathrm{ppm}$ 으로 급격하게 증가하였다. $25^{\circ} \mathrm{C}$ 저장 시 21 일 차 까지 완만하게 증가하였고, 56일까지 급격하게 증가 후 91일 까지 그 수준을 유지하였다. 저장 기간과 저장 온도가 증가할 수록 휘발산 함량의 증가폭이 증가하는 것을 확인할 수 있었 다. 저장 기간과 저장 온도가 증가할수록 휘발산 함량이 증가 하여 식초와 같은 이미 · 이취를 생성하여 관능적 품질에 악

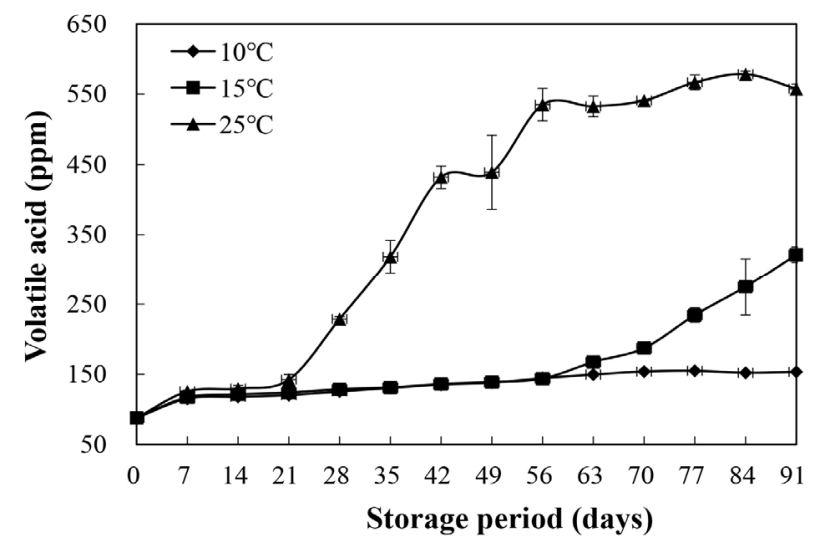

Fig. 6. Changes in volatile acid (ppm) of 'Makgeolli' during storage at different temperatures.
영향을 줄 것으로 추정된다(Jeong 등, 2013).

\section{막걸리의 저장 기간 중 색도 변화}

막걸리 저장 시 색도의 변화는 미생물에 의한 발효 또는 당 및 아미노산 함량 변화 등 화학적 반응에 의한 것으로 보 고되었다(Kim 등, 2007). 따라서 본 연구에서는 저장 기간 중 여러 가지 성분 변화가 예상되어 막걸리의 색도 변화를 확인하고자 하였다. 저장 기간에 따른 저장 온도별 막걸리의 색도 변화는 Table 1-3과 같다. 본 연구에서 저장 초기 0 일 차의 막걸리의 명도는 7.53 , 적색도는 -0.01 , 황색도는 3.11 이 었다. $\mathrm{Kim}$ 등이 연구한 팽화미분 첨가에 따른 막걸리 발효 종료 후의 명도는 74.86 , 적색도는 3.51 , 황색도는 30.11 로 (Kim 등, 2007) 본 연구와 비교해 볼 때 본 연구에서 제조한 막걸리가 명도, 적색도, 황색도 모두 매우 낮았다. 이러한 색 도 차이는 막걸리 제조에 사용되는 원료, 누룩, 첨가물의 종 류 및 투입량이 다르기 때문으로 사료된다(Bae, 2010). $10^{\circ} \mathrm{C}$ 저장 시 91일 차의 명도, 적색도, 황색도는 각각 $9.79,0.02$, 4.15 로 증가하였으나 저장기간에 따른 유의적인 차이는 없었 다. $15^{\circ} \mathrm{C}$ 와 $25^{\circ} \mathrm{C}$ 저장 시 저장 기간에 따른 유의적인 차이를 확인할 수 있었다. $15^{\circ} \mathrm{C}$ 저장 시 91 일 차의 명도, 적색도, 황 색도는 $11.72,0.05,4.61$ 이었고, $25^{\circ} \mathrm{C}$ 저장 시 $14.27,0.09$, 5,47 이었다. 저장 기간과 저장 온도가 증가함에 따라 명도, 적색도, 황색도 모두 증가하는 것을 확인할 수 있었다. $\Delta \mathrm{E}$ 는 전체적인 색도의 차이를 나타내는 수치로 $10^{\circ} \mathrm{C}$ 에서 저장 시 유의적으로 차이가 없었고 $15^{\circ} \mathrm{C}, 25^{\circ} \mathrm{C}$ 에서 저장 시 유의적으 로 차이가 있었으며, $15^{\circ} \mathrm{C}$ 보다 $25^{\circ} \mathrm{C}$ 에서 저장 시 변화가 더 큰 것을 확인할 수 있었다 $(\mathrm{p}<0.05)$. Lee와 Park은 막걸리의 원심 분리한 상등액과 침전물을 저장 시 원심 분리한 상등액 의 경우 명도, 적색도, 황색도에 큰 변화가 없었지만, 침전물 의 경우 높은 명도, 적색도, 황색도 값을 나타냈다고 하였다 (Lee와 Park, 2010). 따라서 본 연구에서 색도의 변화는 침전 물에 의한 것으로 사료된다.

\section{요 약}

본 연구에서는 단행복발효에 의한 막걸리의 저장 온도별 저장 기간에 따른 품질 변화를 알아보았다. 저장 0 일 차 $\mathrm{pH}$ 는 3.86 이었으며, 저장 기간이 경과함에 따라 모든 저장 온 도에서 감소하는 경향을 나타내었다. 총산은 저장 0 일 차에 $0.14 \%$ 이었으며, 저장 91 일 차에 저장 온도 $10^{\circ} \mathrm{C}$ 에서 $0.33 \%$, $15^{\circ} \mathrm{C}$ 에서 $0.35 \%, 25^{\circ} \mathrm{C}$ 에서 $0.40 \%$ 로 저장 기간과 저장 온도 가 증가할수록 총산이 증가하는 경향을 나타내었다. 아미노 산도는 $10^{\circ} \mathrm{C}$ 저장 시 91 일 차에 $0.37,15^{\circ} \mathrm{C}$ 저장 시 91 일 차 에 $0.43,25^{\circ} \mathrm{C}$ 저장 시 91 일 차에 0.55 로 초기 0.11 에서 저장 
Table 1. Changes in color of 'Makgeolli' during storage at $10^{\circ} \mathrm{C}$

\begin{tabular}{ccccc}
\hline $\begin{array}{c}\text { Storage time } \\
\text { (days) }\end{array}$ & $\mathrm{L}^{1)}$ & $\mathrm{a}^{2)}$ & $\mathrm{b}^{3)}$ & $\Delta \mathrm{E}^{4)}$ \\
\hline 0 & $7.53 \pm 0.70^{\mathrm{NS} 5) 6}$ & $-0.01 \pm 0.09^{\mathrm{NS}}$ & $3.11 \pm 0.35^{\mathrm{NS}}$ & $88.55 \pm 0.69^{\mathrm{NS}}$ \\
7 & $7.54 \pm 0.59$ & $-0.02 \pm 0.11$ & $3.17 \pm 0.21$ & $88.55 \pm 0.59$ \\
14 & $8.82 \pm 1.47$ & $0.01 \pm 0.49$ & $4.06 \pm 0.71$ & $86.31 \pm 2.28$ \\
21 & $8.53 \pm 1.41$ & $0.00 \pm 0.35$ & $3.72 \pm 0.53$ & $87.25 \pm 1.69$ \\
28 & $9.06 \pm 0.38$ & $0.02 \pm 0.01$ & $3.95 \pm 0.03$ & $86.39 \pm 0.22$ \\
35 & $8.79 \pm 1.15$ & $0.02 \pm 0.57$ & $4.14 \pm 0.79$ & $85.67 \pm 2.52$ \\
42 & $9.07 \pm 0.74$ & $0.01 \pm 0.17$ & $3.80 \pm 0.22$ & $87.04 \pm 0.73$ \\
49 & $9.29 \pm 2.19$ & $0.03 \pm 0.39$ & $4.46 \pm 1.47$ & $87.21 \pm 2.05$ \\
56 & $9.35 \pm 1.18$ & $0.03 \pm 0.29$ & $4.42 \pm 0.72$ & $85.46 \pm 1.96$ \\
63 & $9.44 \pm 1.93$ & $0.03 \pm 0.48$ & $4.05 \pm 0.85$ & $86.36 \pm 2.30$ \\
70 & $9.40 \pm 1.91$ & $0.02 \pm 0.46$ & $4.04 \pm 0.57$ & $86.73 \pm 1.88$ \\
77 & $9.73 \pm 0.44$ & $0.02 \pm 0.38$ & $4.06 \pm 0.69$ & $86.40 \pm 1.68$ \\
91 & $9.92 \pm 2.17$ & $0.03 \pm 0.56$ & $4.09 \pm 0.82$ & $86.22 \pm 2.43$ \\
\hline
\end{tabular}

${ }^{1)}$ Lightness $(0=$ white, $100=$ black $)$

${ }^{2}$ Redness $(-80=$ green, $+100=$ red $)$.

${ }^{3)}$ Yellowness $(-50=$ blue, $+70=$ yellow $)$.

4) $\Delta \mathrm{E}=\sqrt{\Delta L^{2}+\Delta a^{2}+\Delta b^{2}}$, color difference.

${ }^{5)}$ Each value is mean $\pm \mathrm{SD}(\mathrm{n}=3)$.

${ }^{6}$ Not significant.

Table 2. Changes in color of 'Makgeolli' during storage at $15^{\circ} \mathrm{C}$

\begin{tabular}{|c|c|c|c|c|}
\hline $\begin{array}{l}\text { Storage time } \\
\text { (days) }\end{array}$ & $\mathrm{L}^{1)}$ & $a^{2)}$ & $b^{3)}$ & $\Delta \mathrm{E}^{4)}$ \\
\hline 0 & $7.53 \pm 0.70^{\mathrm{h} 5)}$ & $-0.01 \pm 0.09^{h}$ & $3.11 \pm 0.35^{\mathrm{g}}$ & $88.55 \pm 0.69^{\mathrm{a}}$ \\
\hline 7 & $9.78 \pm 0.48^{\text {efg }}$ & $0.02 \pm 0.06^{\mathrm{efg}}$ & $3.98 \pm 0.14^{\mathrm{ef}}$ & $85.34 \pm 0.62^{\mathrm{def}}$ \\
\hline 14 & $9.92 \pm 9.92^{\text {defg }}$ & $0.03 \pm 0.12^{\text {def }}$ & $4.20 \pm 0.12^{\text {cde }}$ & $85.88 \pm 0.39^{d}$ \\
\hline 21 & $9.23 \pm 0.21^{\mathrm{g}}$ & $0.02 \pm 0.12^{\mathrm{fg}}$ & $3.65 \pm 0.15^{\mathrm{f}}$ & $86.87 \pm 0.20^{\mathrm{b}}$ \\
\hline 28 & $9.43 \pm 0.08^{\mathrm{fg}}$ & $0.01 \pm 0.24^{\mathrm{g}}$ & $3.76 \pm 0.19^{\mathrm{f}}$ & $86.68 \pm 0.09^{b c}$ \\
\hline 35 & $10.01 \pm 0.13^{\mathrm{def}}$ & $0.03 \pm 0.07^{\text {cdef }}$ & $4.14 \pm 0.14^{\text {de }}$ & $86.12 \pm 0.13^{\mathrm{cd}}$ \\
\hline 42 & $10.32 \pm 0.23^{\text {cde }}$ & $0.04 \pm 0.17^{\mathrm{bcd}}$ & $4.23 \pm 0.09^{\text {bcde }}$ & $85.82 \pm 0.22^{\mathrm{d}}$ \\
\hline 49 & $10.56 \pm 0.30^{\mathrm{bcd}}$ & $0.03 \pm 0.06^{\text {cde }}$ & $4.30 \pm 0.29^{\text {abcde }}$ & $85.58 \pm 0.29^{\mathrm{de}}$ \\
\hline 56 & $10.79 \pm 0.32^{\mathrm{abc}}$ & $0.04 \pm 0.09^{\mathrm{abc}}$ & $4.45 \pm 0.14^{\mathrm{abcd}}$ & $85.36 \pm 0.32^{\mathrm{def}}$ \\
\hline 63 & $11.19 \pm 0.18^{\mathrm{ab}}$ & $0.05 \pm 0.14^{\mathrm{ab}}$ & $4.59 \pm 0.14^{\mathrm{abc}}$ & $84.97 \pm 0.17^{\mathrm{ef}}$ \\
\hline 70 & $11.36 \pm 0.23^{\mathrm{a}}$ & $0.05 \pm 0.07^{\mathrm{ab}}$ & $4.66 \pm 0.08^{\mathrm{a}}$ & $84.80 \pm 0.23^{\mathrm{ef}}$ \\
\hline 77 & $11.40 \pm 0.88^{\mathrm{a}}$ & $0.06 \pm 0.13^{\mathrm{a}}$ & $4.45 \pm 0.22^{\mathrm{abcd}}$ & $84.61 \pm 0.66^{\mathrm{f}}$ \\
\hline 84 & $11.08 \pm 0.67^{\mathrm{ab}}$ & $0.06 \pm 0.17^{\mathrm{ab}}$ & $4.37 \pm 0.39^{\mathrm{abcd}}$ & $85.00 \pm 0.75^{\mathrm{ef}}$ \\
\hline 91 & $11.72 \pm 0.35^{\mathrm{a}}$ & $0.05 \pm 0.18^{\mathrm{ab}}$ & $4.61 \pm 0.11^{\mathrm{ab}}$ & $84.75 \pm 0.35^{f}$ \\
\hline
\end{tabular}

${ }^{1)}$ Lightness $(0=$ white, $100=$ black $)$.

${ }^{2)}$ Redness $(-80=$ green,$+100=$ red $)$.

${ }^{3)}$ Yellowness $(-50=$ blue, $+70=$ yellow $)$.

4) $\Delta \mathrm{E}=\sqrt{\Delta L^{2}+\Delta a^{2}+\Delta b^{2}}$, color difference.

${ }^{5)}$ Mean \pm SD ( $n=3$ ) within each column followed by different letters are significantly different $(\mathrm{p}<0.05)$ 
Table 3. Changes in color of 'Makgeolli' during storage at $25^{\circ} \mathrm{C}$

\begin{tabular}{|c|c|c|c|c|}
\hline $\begin{array}{l}\text { Storage time } \\
\text { (days) }\end{array}$ & $L^{1)}$ & $a^{2)}$ & $b^{3)}$ & $\Delta \mathrm{E}^{4)}$ \\
\hline 0 & $7.53 \pm 0.70^{\mathrm{f5})}$ & $-0.01 \pm 0.09^{\mathrm{f}}$ & $3.11 \pm 0.35^{\mathrm{d}}$ & $88.55 \pm 0.69^{\mathrm{a}}$ \\
\hline 7 & $10.37 \pm 0.23^{\text {cde }}$ & $0.04 \pm 0.17^{\mathrm{e}}$ & $4.10 \pm 0.12^{\mathrm{c}}$ & $85.42 \pm 0.46^{\mathrm{bcd}}$ \\
\hline 14 & $10.11 \pm 0.17^{\mathrm{e}}$ & $0.04 \pm 0.15^{\mathrm{e}}$ & $4.01 \pm 0.09^{\mathrm{c}}$ & $86.01 \pm 0.16^{\mathrm{b}}$ \\
\hline 21 & $10.20 \pm 0.20^{\mathrm{de}}$ & $0.05 \pm 0.10^{\mathrm{de}}$ & $4.03 \pm 0.13^{\mathrm{c}}$ & $85.93 \pm 0.19^{\mathrm{bc}}$ \\
\hline 28 & $10.42 \pm 0.16^{\mathrm{cde}}$ & $0.06 \pm 0.04^{\mathrm{de}}$ & $4.08 \pm 0.07^{\mathrm{c}}$ & $85.71 \pm 0.16^{\text {bcd }}$ \\
\hline 35 & $10.51 \pm 0.02^{\text {cde }}$ & $0.06 \pm 0.05^{\mathrm{de}}$ & $4.01 \pm 0.03^{\mathrm{c}}$ & $85.62 \pm 0.02^{\mathrm{bcd}}$ \\
\hline 42 & $10.57 \pm 0.19^{\text {cde }}$ & $0.06 \pm 0.06^{\text {cde }}$ & $3.95 \pm 0.05^{\mathrm{c}}$ & $85.55 \pm 0.19^{\mathrm{bcd}}$ \\
\hline 49 & $11.42 \pm 0.48^{\text {bcde }}$ & $0.07 \pm 0.06^{\text {bcde }}$ & $4.32 \pm 0.12^{\mathrm{bc}}$ & $84.72 \pm 0.48^{\text {bcde }}$ \\
\hline 56 & $11.36 \pm 0.14^{\text {bcde }}$ & $0.07 \pm 0.18^{\mathrm{abcd}}$ & $4.17 \pm 0.29^{\mathrm{c}}$ & $84.77 \pm 0.14^{\text {bcde }}$ \\
\hline 63 & $11.79 \pm 0.21^{\text {bcde }}$ & $0.07 \pm 0.11^{\mathrm{abcd}}$ & $4.52 \pm 0.27^{\mathrm{bc}}$ & $84.37 \pm 0.19^{\text {bcde }}$ \\
\hline 70 & $12.05 \pm 0.17^{\mathrm{bcd}}$ & $0.07 \pm 0.08^{\mathrm{abcd}}$ & $4.58 \pm 0.08^{\mathrm{bc}}$ & $84.10 \pm 0.17^{\text {cde }}$ \\
\hline 77 & $12.17 \pm 1.03^{\mathrm{bc}}$ & $0.08 \pm 0.26^{\mathrm{abc}}$ & $4.68 \pm 0.40^{\mathrm{bc}}$ & $83.99 \pm 0.69^{\text {de }}$ \\
\hline 84 & $12.61 \pm 0.33^{\mathrm{ab}}$ & $0.09 \pm 0.06^{\mathrm{ab}}$ & $4.96 \pm 0.19^{\mathrm{ab}}$ & $83.27 \pm 0.22^{\mathrm{ef}}$ \\
\hline 91 & $14.27 \pm 3.34^{\mathrm{a}}$ & $0.09 \pm 0.60^{\mathrm{a}}$ & $5.47 \pm 1.30^{\mathrm{a}}$ & $82.18 \pm 3.34^{\mathrm{f}}$ \\
\hline
\end{tabular}

${ }^{1)}$ Lightness $(0=$ white, $100=$ black $)$.

${ }^{2)}$ Redness $(-80=$ green, $+100=$ red $)$.

${ }^{3)}$ Yellowness $(-50=$ blue, $+70=$ yellow $)$

4) $\Delta \mathrm{E}=\sqrt{\Delta L^{2}+\Delta a^{2}+\Delta b^{2}}$, color difference.

${ }^{5} \mathrm{Mean} \pm \mathrm{SD}(\mathrm{n}=3)$ within each column followed by different letters are significantly different $(\mathrm{p}<0.05)$.

기간과 저장 온도가 증가할수록 증가하는 경향을 나타내었 다. 또한, 저장 기간과 저장 온도가 증가할수록 휘발산 함량 의 증가폭이 커지는 것을 확인할 수 있었다. 반면, 가용성 고 형분, 알코올은 큰 차이를 나타내지 않았다. $\Delta \mathrm{E}$ 는 전체적인 색도의 차이를 나타내는 것으로 $10^{\circ} \mathrm{C}$ 에서 저장 시 유의적으 로 차이가 없었고 $15^{\circ} \mathrm{C}, 25^{\circ} \mathrm{C}$ 에서 저장 시 유의적으로 차이 가 있었으며, $15^{\circ} \mathrm{C}$ 보다 $25^{\circ} \mathrm{C}$ 에서 저장 시 변화가 더 큰 것을 확인할 수 있었다. 결과적으로 저장 기간이 증가할수록 품질 변화가 발생하는 것을 확인할 수 있었고, 저장 온도가 높을 수록 품질 변화가 빠른 것을 확인할 수 있었다. 막걸리의 유 통 온도가 $10^{\circ} \mathrm{C}$ 이므로 저장 온도를 10,15 , 및 $25^{\circ} \mathrm{C}$ 로 설정 하여 품질 변화를 살펴보았지만 저장 온도가 냉장 온도인 $4^{\circ} \mathrm{C}$ 에서 단행복발효 막걸리의 품질 변화가 더 적을 것으로 사료된다.

\section{감사의 글}

본 연구는 국립농업과학원 농업과학기술 연구개발사업(과 제번호: PJ0134302020)의 지원에 의해 이루어진 것이며, 연 구비 지원에 감사드립니다.

\section{Conflict of interests}

The authors declare no potential conflict of interest.

\section{ORCID}

Jeong Sil Choi https://orcid.org/0000-0002-9036-0047

Seok Tae Jeong https://orcid.org/0000-0001-9997-2763

\section{References}

Bae IY, Woo JM, Yoon EJ, Kim JS, Lee HG, Yang CB. The development of Korean traditional wine using the fruits of Opuntia ficus-indica var. saboten-II. characteristics of liquors. J Korean Soc Agric Chem Biotechnol, 45, 59-65 (2002)

Bae SJ. Well-being Traditional Wine Makgeolli. Hanam Publication, Seoul, Korea, p 18, 76 (2010)

Bae SM, Kim HJ, Oh TK, Kho YH. Preservation of Takju by pasteurization. Korean J App Microbiol Biotech, 18, 
322-325 (1990)

Baek SY, Nam YG, Ju JI, Lee JS. Changes of quality characteristics during storage of Gugija-Liriope tuber Makgeolli made by Saccharomyces cerevisiae C-2. Korean J Mycol, 39, 122-125 (2011)

Cheong C, Rhee IS, Lee SK, Kang SA. A study on the qualitative properties of traditional sake using Allbanggae. J Korean Soc Food Sci Nutr, 37, 784-791 (2015)

Choi GI, Kim HJ, Kim HJ, Kim HR, Kim DH, Ahn JS, Son YG, Song IH. Changes of organic acids in Takju during storage conditions. J Food Hyg Safety, 27, 127-132 (2012)

Graham HF. Wine Microbiology and Biotechnology. Harwood Academic Publishers, New York, NY, USA, p 400-401 (1993)

Jang GY, Lee SH, Li M, Kim ST, Lee JH, Kang TS, Lee JY, Lee JS, Jeong HS. Quality characteristics at different storage temperature and periods for shelf life evaluation of Takju. Korean J Food Nutr, 28, 104-110 (2015)

Jeong C, Park CS, Yeo SH, Jo HC, Noh BS. Brewing Science. Kwangmoonkag Co, Paju, Korea, p 78 (2015) Jeong JW, Park KJ, Kim MH, Kim DS. Quality characteristics of Takju fermentation by addition of chestnut peel powder. Korean J Food Preserv, 13, 329-336 (2006) Jeong ST, Kwak HJ, Kim SM. Quality characteristics and biogenic amine production of Makgeolli brewed with commercial Nuruks. Korean J Food Sci Technol, 45, 727-734 (2013)

Jung JH, Jung ST. The changes of quality and microflora during the preservation of Korean Takju. J Korean Soc Appl Biol Chem, 28, 252-260 (1985)

Jwa MK, Lim SB, Mok CK, Park YS. Inactivation of microorganisms and enzymes in foxtail millet Takju by high hydrostatic pressure treatment. Korean J Food Sci Technol, 33, 226-230 (2001)

Kang JE, Choi HS, Choi JH, Yeo SH, Jeong ST. Physicochemical properties of Korean non-sterilized commercial Makgeolli. Korean J Community Living Sci, 25, 363372 (2014)

Kim BH. Establishment for best-before date of quality index in Makgeolli stored at refrigerated temperature. MS Thesis, Chonnam National University, Korea, p 26-34 (2012)

Kim CJ. Studies on the quantitative changes of organic acid and sugars during the fermentation of Takju. J Korean Soc Agr Chem Biotechnol, 4, 33-42 (1963)

Kim JY, Sung KW, Bae HW, Yi YH. pH, acidity, color, reducing sugar, total sugar, alcohol and organoleptic characteristics of puffed rice powder added Takju during fermentation. Korean J Food Sci Technol, 39, 266-271 (2007)

Kim MJ, Lee SY, Kim KBWR, Song EJ, Kim AR, Kim JH, Ji KW, Ahn IS, Ahn DH. Effect of chitosan on shelf-life and quality of Takju. J Chitin Chitosan, 12, 198-204 (2007)

Kim SM, Han AR. Storage properties and biogenic amines production of Makgeolli brewed with different proportions of rice and wheat flour. Korean J Food Sci Technol, 44, 583-591 (2012)

Lee CH, Lee HD, Kim JY, Kim KM. Sensory quality attributes of Takju and their changes during pasteurization. Korean J Diet Cult, 4, $405-410$ (1989)

Lee $\mathrm{CH}$, Tae WT, Kim GM, Lee HD. Studies on the pasteurization conditions of Takju. Korean J Food Sci Technol, 23, 44-51 (1991)

Lee JS, Lee TS, Noh BS, Park SO. Quality characteristics of mash of Takju prepared by different raw materials. Korean J Food Sci Technol, 28, 330-336 (1996)

Lee JW, Jung JJ, Choi EJ, Kang ST. Changes in quality of UV sterilized Takju during storage by honeycomb type-UV sterilizer. Korean J Food Sci Technol, 41, 652-656 (2009)

Lee JW, Park JW. Quality characteristics of Makgeolli during separation storage methods. Food Eng Prog, 14, 346-353 (2010)

Lee TJ, Hwang DY, Lee CY, Son HJ. Changes in yeast cell number, total acid and organic acid during production and distribution processes of Makgeolli, traditional alcohol of Korea. Korean J Microbiol, 45, 391-396 (2009)

Lee ZS, Rhee TW. Studies on the microflora of Takju brewing. Korean J Microbiol, 8, 116-133 (1970)

National Tax Service Liquors License Support Center. Analysis Regulations of Alcoholic Beverages. National Tax Service Liquors License Support Center, Seoul, Korea, p 39-43 (2014)

Park CW, Jang SY, Park EJ, Yeo SH, Kim OM, Jeong YJ. Comparison of the quality characteristics of commercial 
Makgeolli type in South Korea. Korean J Food Preserv, $18,884-890$ (2011)

Rogerson F, Symington C. A method for the estimation of alcohol in fortified wines using hydrometer Baume and refractometer Brix. Am J Enol Vitic, 57, 486-490 (2006)

Ryu IS. Korean Traditional Liquor Text Book. Kyomunsa Publishing Company Co, Paju, Korea, p 30-33 (2014)
Son HS, Park BD, Ko BK, Lee CH. Quality characteristics of Takju produced by adding different amounts of water. Korean J Food Sci Technol, 43, 453-457 (2011)

Song JC, Park HJ, Shin WC. Change of Takju qualities by addition of cyclodextrin during the brewing and aging. Korean J Food Sci Technol, 29, 895-900 (1997) 